\title{
Samarbejde mellem bibliotek og fagbevægelse i Århus
}

\author{
Af Hanne Marie Knudsen og Dorthe Larsen
}

\section{Projekt "Bibliotek og Fagforening"}

Specialarbejderforbundet i Danmark (SID) og Århus Kommunes Biblioteker (ÅKB) har fra januar 1989 til 1991 været involveret $i$ et forsøg med bibliotekstilbud i lokalafdelinger af SID i Århus og på en større virksomhed.

Den afgørende begrundelse for projekt "Bibliotek og Fagforening" er, at faglærte og ufaglærte arbejdere bruger folkebibliotekerne langt mindre end gennemsnittet af befolkningen. Iflg. "Fritidsundersøgelsen 1987" bruger kun ca. $20 \%$ af faglærte og ufaglærte arbejdere bibliotekernes tilbud, mens mellem $33 \%$ og $50 \%$ af funktionærgruppen bruger bibliotekerne.

Der har været spredte tiltag til oprettelse af arbejdspladsbiblioteker i Danmark. Arbejdspladsbibliotekerne har som oftest været en succes. Men de er desværre aldrig blevet til en integreret del af bibliotekernes virksomhed.
Da SID og ÅKB i 1988 indledte et samarbejde, var man enige om ikke i første omgang at satse på oprettelse af arbejdspladsbiblioteker. I stedet ville man etablere biblioteksafdelinger på de lokale fagforeningskontorer. "Fagforeningsbibliotekerne" skulle dels bestå af et fagligt håndbogsbibliotek til hjælp for de ansatte på fagforeningskontorerne, tillidsmænd og sikkerhedsrepræsentanter i deres arbejde, og dels af et almindeligt folkebibliotekstilbud. Fagforeningsbibliotekerne skulle danne bro til arbejdspladserne. Formænd, bestyrelser, tillidsmænd skulle således fungere som bindeled.

\section{Fagforeningsbibliotekerne}

Der blev i løbet af 1989 oprettet fagforeningsbiblioteker i SID Jern \& Metal Århus, SID Århus Kommunale og SID Fabrik.

Fagforeningsbibliotekerne har været placeret centralt på de enkelte fagforeningskontorer. Nye aktuelle materialer har med glitrende forsider været 
blikfang for medlemmerne, når de er kommet på fagforeningskontoret. Materialerne har været opdelt i emner, der er velkendte for fagforeningsmedlemmerne. Der har været en god og overskuelig skiltning. Vi har været på fagforeningskontorerne i ca. halvdelen af åbningstiden. Vi har således været en del af staben på fagforeningskontoret, som medlemmerne kender. Samtididig har det været afgørende, at man på hvert fagforeningskontor har udpeget en ansvarlig biblioteksperson, som også er gået ind i biblioteksopgaverne og formidlingen heraf med ildhu.

Udvalget af materialerne har vi naturligvis drøftet med vore samarbejdspartnere $i$ de enkelte fagforeninger. Den eneste klausul, vi fra starten fik fra fagforeningsfolkene var, at man under ingen omstændigheder ville have racistisk litteratur på hylderne.

\section{Besøg på arbejdspladser}

Vi har besøgt mange arbejdspladser. Disse besøg har været en vigtig del af informationsarbejdet om projektet. Besøgene er kommet i stand via de gode kontakter med bestyrelser og tillidsmænd. Besøgene har ofte formet sig som en kombination af en faglig snak og en præsentation af fagforeningsbiblioteket. Vi har også deltaget i studiekredsvirksomhed, hvor der har været aflagt besøg på enkelte virksomheder.

I 1990 etablerede vi i samarbejde med fællestillidsmanden på Aarhus Oliefabrik et ugentligt bibliotekstilbud af en times varighed. Det har været en stor succes, og i øjeblikket benytter $30 \%$ af fabrikkens ansatte bibliotekstilbudet.

\section{Svenske erfaringer med arbejdspladsbiblioteker}

Bibliotek på arbejdspladsen er et almindeligt kulturelt indslag $\mathrm{i}$ arbejdslivet i Sverige. Det skyldes for det første, at det svenske biblioteksvæsen prioriterer det opsøgende biblioteksarbejde højt, for det andet, at det svenske Socialdemokrati og svensk fagbevægelse opfatter kulturtilbud på arbejdspladsen som et væsentligt element $\mathrm{i}$ deres kulturpolitik.

Især i 1980'erne er der p.g.a. mulighed for statstilskud til denne virksomhed oprettet mange arbejdspladsbiblioteker. Erfaringerne med arbejdspladsbibliotekerne er positive: Bibliotekstilbudene bruges af mellem halvdelen og to trediedele, og arbejdspladsbibliotekerne har en tydelig læsefremmende effekt.

Her i begyndelsen af 1990'erne reduceres antallet af arbejdspladsbiblioteker igen p.g.a. statslige og kommunale besparelser.

I januar 1991 afholdt Statens Kulturråd og Stockholms stadsbibliotek en konference "Har arbetsplatsbiblioteken en framtid" i Stockholm. Konferencen peger på, at arbejdspladsbibliotekernes fortsatte succes forudsætter, at bogombudsmændene i langt højere grad selv skal drive denne kulturvirksomhed på arbejdspladserne. Modellen med de to eller fire bibliotekarbesøg på en arbejdsplads om måneden hører fortiden til. Men man er dog enige om, at bibliotekaren fortsat vil være en vigtig ressource at trække på for bogombudsmændene. Det er også vores erfaring fra projekt " Bibliotek og Fagforening", at hvor fagbevægelsens repræsentanter selv har været engagerede og involverede omkring bibliotekstilbudet har det fungeret godt. Konferencen peger også på, at det af ressourcemæssige grunde er nødvendigt, at virksomhederne fremover er med til at financiere arbejdspladsbibliotekerne. En del svenske virksomheder financierer allerede arbejdspladsbibliotekstilbudet. Et konkret eksempel fra en virksomhed i Stockholm: Engangsbeløb 3.000 sv. kr., løbende drift på. år $150 \mathrm{sv}$. kr. pr. ansat. At det kan lade sig gøre, skyldes naturligvis traditionen og den politiske opbakning i Sverige.

\section{Erfaringerne med projekt "Bibliotek og Fag- forening"}

Dorte Skot-Hansen fra Danmarks Biblioteksskole i København og Lars Qvortrup fra Odense Univer- 
sitetscenter har evalueret projektet "Bibliotek og Fagforening". "Rapport om forsøg med fagforenings- og arbejdspladsbiblioteker, SID, 1991" er netop udkommet.

Rapporten konkluderer, at forsøget har været en succes. Fagforeningsbibliotekernehar skabt kontakt med traditionelle ikke-bibliotekslånere, idet $40 \%$ af lånerne i fagforeningsbibliotekerne og arbejdspladsbiblioteket ikke tidligere brugte folkebiblioteket. Endvidere har det vist sig, at $12 \%$ af dem, som brugte fagforenings- eller arbejdspladsbiblioteket, og som ikke tidligere brugte folkebiblioteket, siden hen er blevet lånere på de "rigtige" folkebiblioteker.

Det fremhæves i rapporten, at årsagen til, at så mange ikke bruger bibliotekerne, er selve "institutionen". Biblioteket er for mange så fremmed en verden, at det at bevæge sig ind i biblioteket er den største barriere. Den næstvigtigste grund er, at man selv køber eller lejer de materialer, man har brug for.
En stor del af udlånene i fagforeningsbibliotekerne er billed- og lydmaterialer: $44 \%$ af udlånet har ligget på disse materialetyper, musikken alene har tegnet sig for $20 \%$ af det samlede udlån. $47 \%$ af det samlede udlån har været bøger. Det ligner jo ikke fordelingen fra folkebibliotekerne $i$ almindelighed.

Fra SID og de involverede afdelinger har det været en positiv effekt af forsøget, at fagbevægelsen i en periode, hvor man tilstræber at udvide servicen over for medlemmerne til andet og mere end løn og arbejdsvilkår, har kunnet profilere sig på det kulturelle område. Man har været tilfredse med at få det kulturelle aspekt med i viften af medlemstilbud, og i en tid, hvor der satses på viden, uddannelse og efteruddannelse, har man anset det for vigtigt, at fagforeningerne definerer deres rolle på biblioteksområdet.

\section{Hvad slags materialetyper blev udlånt?}

Udlån i alt fordelt på matrialetyper i \%.

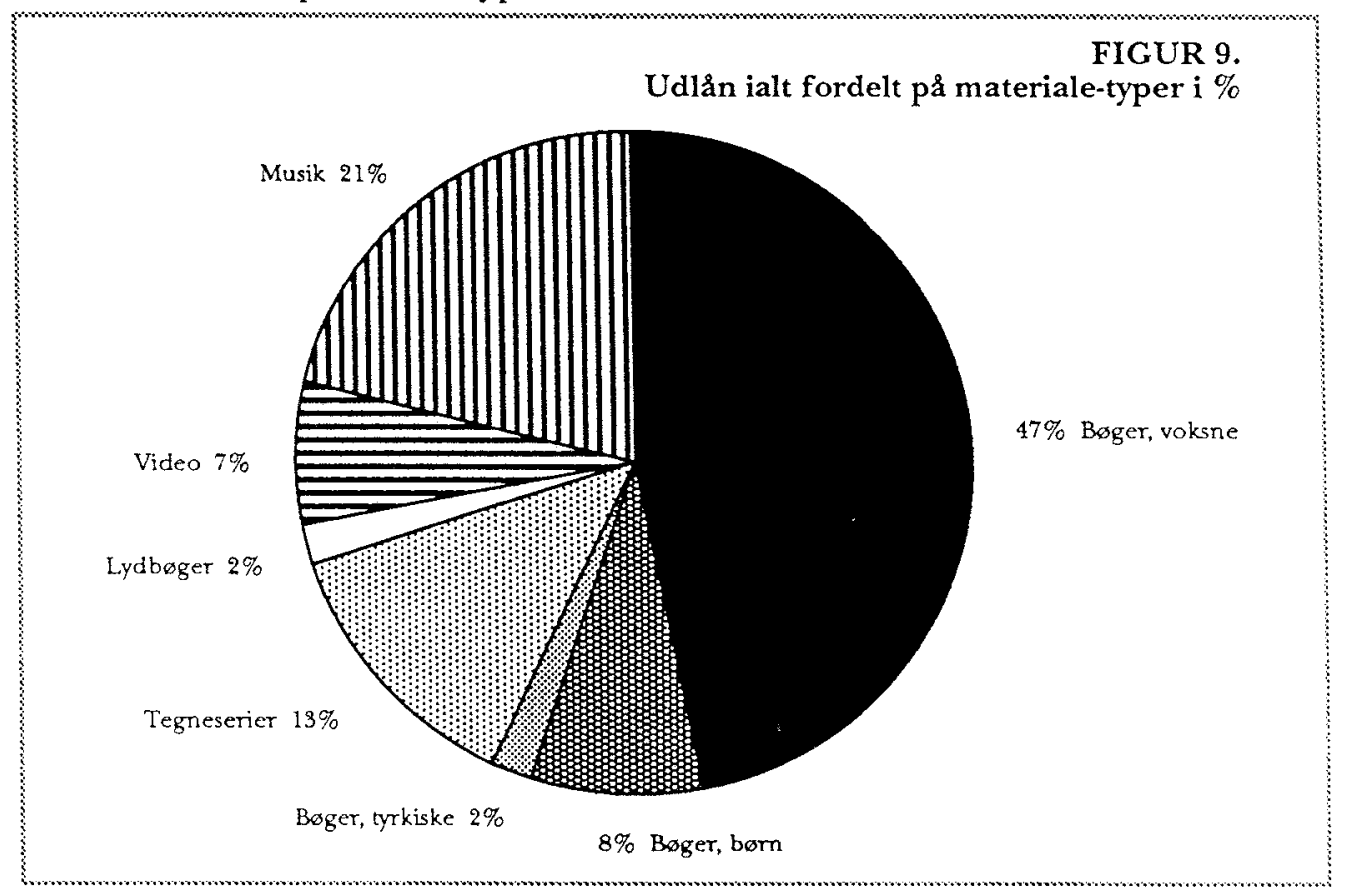




\section{Bibliotekarer og projektarbejde}

Vores motiver til at gå ind i projekt "Bibliotek og Fagforening" har fra starten været meget forskellige. En af os har siden 1970'erne været meget interesseret i kulturpolitisk samarbejde med fagbevægelsen om ikke-bruger problematikken, og var en af initiativtagerne bag henvendelsen til den lokale fagbevægelse i 1987.

For den anden af os var motivet et ønske om at prøve at være ansat som projektmager og at lære noget om projektarbejde $i$ et forum med så vidt forskellige samarbejdspartnere. Vi har begge fået vore motiver indfriet, og vi har også begge fået inspiration både menneskeligt og fagligt. $\mathrm{Og}$ især er vi blevet bekræftet $i$, at der må og skal ske ændringer $\mathrm{i}$ vort biblioteksvæsen, hvis vi vil imødekomme de mange forskellige behov fra folk, der ikke normalt kommer på folkebibliotekerne. Det er ikke ligegyldigt, hvordan man arbejder med projekter, og hvordan man samarbejder med samarbejdspartnerne "udefra". I vort tilfælde gjaldt det om fra starten at nedbryde nogle af de mange forståelseskløfter og kulturbarrierer, der fortsat findes mellem fagbevægelsens repræsentanter og bibliotekarer.

Vi blev opfattet som repræsentanter fra en finkulturel institution, - og vi havde ikke på forhånd givet indtryk af "at have et afklaret forhold til arbejderbevægelsen" (=medlemskab af socialdemokratiet). Vi opfattede til gengæld dem som nogle af de tunge drenge fra den århusianske fagbevægelse. Kort sagt: det var vidt forskellige organisationskulturer, vi kom fra - til gengæld havde vi fælles interesser for organisationsarbejde $i$ almindelighed. Og den ballast i rygsækken har nok i dette tilfælde været en lige så stor fordel som de rent biblioteksfaglige erfaringer, vi også havde at bidrage til samarbejdet med.

Men helt overordnet synes vi, det også handler om at bruge sig selv fuldt ud med de evner og den energi, man ligger inde med. Vi har under hele projektperioden haft den politik altid at sige ja, når vi af vore samarbejdspartnere blev inviteret til at bidrage til eller deltage $i$ et fagforeningsarrangement. Vi har derfor også deltaget $\mathrm{i}$ afdelingernes sociale liv lige fra kaffedrikning til bryllup og fødselsdage.

\section{Nye perspektiver og fremtiden}

Opsøgende og tværgående samarbejde er en nødvendighed, hvis man vil i kontakt med de grupper, der ikke til daglig benytter sig af folkebibliotekerne. Det er fantastisk vigtigt at hente inspiration fra samarbejdet med andre organisationer og institutioner og at lære af deres kultur og hele tiden forsøge at bearbejde og videregive de indhøstede erfaringer.

Først og fremmest handler det om holdningsændringer i personalet, når det gælder om at betjene dem, der normalt ikke benytter bibliotekerne. Alt for ofte ser vi, at ressourcerne hos personalet $i$ mange biblioteker primært og umærkeligt går til at betjene uddannelsessøgende og andre biblioteksvante personer. Det skyldes, at der i Danmark næsten ikke findes egentlige skolebiblioteker på ungdomsuddannelsernes institutioner eller inden for folkeoplysningsområdet eller voksenundervisningen.

Målsætningsdiskussioner for hele bibliotekspersonalet om hvilke grupper, man reelt ønsker at prioritere, er nødvendige, hvis personalet skal blive bevidst om situationen.

Forudsat man ønsker at komme ikke-biblioteksvante folk i møde, er biblioteksindretningen en vasentlig faktor. Opbrud i decimalklassedelingen og storre overskuelighed er kodeordene. I dette udviklingsarbejde er det helt oplagt at hente inspiration fra det kommercielle marked for eksempel fra de salgs- og PR-metoder, som supermarkeder og andre større forretninger bruger eller fra musikhandlernes strålende og støjende vinduer.

En anden vigtig faktor er at lagge vægten på lydog billedsiden i materialevalget. Musikken er endnu engang bevist - et medie, som alle befolk- 
ningsgrupper benytter sig af. "Billedgenerationen", som de unge også kaldes i dag, har andre ønsker og behov $i$ deres søgen efter information og oplevelser. Derfor må vi fastslå, at det er uhyre vigtigt $i$ materialevalget at tage udgangspunkt $i$ de aktuelle medievaner eksempelvis den unge generations forbrug af videoer og musik.

I SID fagforeningerne har man også ladet sig inspirere.

SID Århus Kommunale, en af forsøgsafdelingerne, har således besluttet at fortsætte med biblioteket som en kulturpolitisk prioritering i fagforeningsarbejdet. Det vil sige, at de selv afsatter midler til nye materialer samt til fire bibliotekartimer om ugen. Der er indgået en samarbejdsaftale med $\AA$ KB om depotordning m.m.

Ligeledes fortsætter bibliotekstilbudet på Aarhus Oliefabrik som en del af ÅKB's opsogende arbejde. Tillidsmændene på virksomheden, der har været aktive i forbindelse med bibliotekstilbudet, ønsker nu selv at forestå udlån af materialerne.
Et netværk, der skal videreudvikle samarbejdet mellem bibliotek og fagforening, er ved at blive etableret. På kort sigt drejer det sig om at finde nye samarbejdspartnere i den lokale fagbevægelse og på større arbejdspladser. Der er også planer om at etablere et kursustilbud for de involverede kulturtillidsmænd. Perspektiverne $\mathrm{i}$ dette er at netværket på længere sigt skal skabe forståelse for kulturtillidsmandstanken. Det vil sige, at kulturarbejdet skal have status som en del af det faglige arbejde på arbejdspladsen. Kulturarbejdet kan eksempelvis bestå af kunstformidling, bogformidling, aftenskoleundervisning, frimærkeklub og videofremvisning. Målet er at skabe en kulturtillidsmandsuddannelse $i$ fagbevægelsens interne uddannelsessystem på landsplan.

Århus Kommunes Biblioteker har trods generelle nedskæringer prioriteret en halv bibliotekarstilling til en videreudvikling af samarbejdet med fagbevægelsen i Århus og til opsøgende arbejde i forhold til almen voksenuddannelse. Det er sket i erkendelse af, at det opsøgende arbejde over for dem, der ikke bruger bibliotekerne, må gøres til en del af bibliotekernes virksomhed, hvis der i praksis skal sikres lige adgang til bibliotekernes informations- og kulturtilbud.

Finansiering af projekt BIBLIOTEK OG FAGFORENING

Staten. Folkebibliotekernes rådighedssum:

$490.000 \mathrm{kr}$.

Århus Kommunes Biblioteker:

$120.000 \mathrm{kr}$.

SID. Hovedforbundet

$240.000 \mathrm{kr}$.

SID lokalt

$70.000 \mathrm{kr}$.

I alt

$920.000 \mathrm{kr}$. 